Trivent Publishing

(C) The Authors, 2015

Available online at http://trivent-publishing.eu/

Philosophy, Communication, Media sciences Series

Volume Saint Gerard of Cenad: Tradition and Innovation

\title{
Christening Names in Cenad
}

\author{
Dușan Baiski \\ Uniunea Scriitorilor din România (Romanian Writer's Union) \\ dusanbaiszki@gmail.com
}

\begin{abstract}
The subject of this article deals with the Christening names of Orthodox Romanians from the town of Cenad, Romania. The Study was done based on documents related to christening between 1976-1903 and 2011-2013. In Christening names in the registers of religious cults in Cenad have changed, in time, based on various influences, adaptations, and spellings. Until the beginning of the twentieth century, the most dominant names were those of Biblical influence, regardless of the child's nationality. After 1989 however, christening names specific to other regions started to emerge because of the influence of mass media, the freedom to travel, the freedom to marry foreign citizens, but also because of the influence of new inhabitants of Cenad who originated elsewhere. While Biblical names used to be dominant, they now entered the minority sphere.
\end{abstract}

\section{Keywords}

Cenad; name; biblical; time; influence; cult; adaptation; minority. 
Motto: Nobody will stand by the Gates of Heaven to check if a name is in line with the Christian calendar, in order to open the Gates or not. The Gates will open according to our faith and deeds.

Anonymous priest

While the problem of christening names is more or less problematic, it becomes critical when a newborn appears in the family. Of course, one must overlook the fact that the most desired children were boys which resulted in numerous family dramas. Even in the contemporary society, men are bestowed with the role of the "warrior" (defender or conqueror), while women remain in secondary role: being a mother and a housewife - consequently, the names must also incorporate these roles.

This analysis must start with the definition of the noun "name," taken from the Romanian Explicative Dictionary: ${ }^{1}$

NAME, names. A word or a group of words which denote a person, a thing, an action, a notion, etc., through which this person, thing, action, notion, etc. identifies. $\diamond$ Christening name $=$ first name. Family name $=$ a name worn by all the members of the same family and which is transmitted from parents to children. Name day $=$ a day in which on celebrates his/her name. ${ }^{2}$

What is of interest in this definition is the christening name or the first name. There is a wide literature dealing with this subject which supported the present study - among which, the names of the Greek-Orthodox inhabitants of the Cenad settlement between 1876 and 1903, as well as between 2011 and 2013; furthermore, extracts from Church records were used, as well as a series of analyses and considerations regarding the past and present tendencies in anthroponymy.

It should be highlighted from the beginning that there are two aspects of the Cenad christening name problematic: one regarding the position of the Church towards christening names and the other regarding the position of lay authorities - the two not being interconnected anymore. Therefore, although until the twentieth century, the child had to be christened immediately after birth, the fist concern of parents today is to declare the new birth to the authorities and only afterwards to christen the child. Concerning christening names, Greek-Orthodox churches have their own Synaxaria. ${ }^{3}$ Nevertheless, as laity is not always in concordance with the written and non-written Church laws, it often happens that the two institutions enter conflict. While, for instance, most autocephalous eastern churches christen with any name (except those with satanic implications), the Russian Orthodox Church had a more strict position, its priests refusing to perform the Holy Mysteries on Christians christened in local churches if their names were not in the calendar. As a consequence, the Patriarchate of Moscow had to intervene.

The successive arrivals of Slavic people who settled on the Balkans (thus also in the Banat region, which incorporates Cenad) had a profound impact on the christening names of local Wallachians. Furthermore, the introduction of Old Church Slavonic as the liturgical language in the area had a final impact in the names. The first ones who adopted Slavic names or names derived from Slavic were members of the local nobility. Therefore, some Romanian regions (such as Moldavia) incorporated as much as two thirds of Slavic names. The first Wallachian voivodes and their relatives bore Slavic names such as Dragoş, Bogdan, Litovoi, Seneslav, or Tihomir, all known from documents and chronicles. Some of these names are accompanied by a number of Slavic derivates, to which some other derivates were added later on, in the Romanian language. ${ }^{4}$

\footnotetext{
${ }^{1}$ Because the study based on the christening names of the people of Cenad, a Romanian dictionary had to be used. See: http://dexonline.ro (last time accessed: July 6, 2015).

${ }^{2}$ See: http://dexonline.ro/definitie/nume (last time accessed: July 6, 2015).

${ }^{3}$ Synaxaia are lists of the saints arranged in the order of their anniversaries.

${ }^{4}$ Ana Marin, Considerații privind interferențele româno-sud-slave în antroponimie [Considerations regarding South Slavic Romanian interferences in antroponymy] (Constanța: Ovidius University Annals of Philology Vol. XIII, 2002), 149-158.
} 
Others however, although they accept the large share of Slavic names in Romanian anthroponymy, consider that "...it is too large, but not because of objective reasons, but subjective ones, of the authors of collections of etymologies; more precisely the authors of dictionaries or etymology works did some condemnable insufficiencies, such as not applying the principle of internal etymology ... as well as not applying the principle according to which <the origin of a word [thus, of a name] must be first of all sought in the Romanian language, in its system of word formation [thus, of names].>"

Furthermore, the names in the Ardeal and Banat region of today's Romania went through a transition towards the Hungarian language both in the way they were written and in the way they were pronounced. Being unhappy about this outcome, the local Romanian intellectuals sought to avoid such influences by updating the Latin onomasticom, which did not have names with Hungarian connections. ${ }^{6}$ The Romanian priests and teachers of Cenad quickly adapted to this new current as it will be seen further on.

Because minority first names were changed with Romanian equivalents during the communist period (Erzsébet - Elisabeta; Miklós - Nicolae; Tibor - Tiberiu; Gyula - Iuliu; György - Gheorghe), the Hungarians started to use original Hungarian names which did not have a Romanian equivalent: Csaba, Béla, Levente, Zsolt (for boys), and Csilla, Gyöngyvér, Réka, Emese (for girls). Similarly, Serbian names were now transcribed according to the Romanian orthography and alphabet: Jeftić Ieftici, Dušan - Dușan, Jadranka - Iadranca, Božidar - Bojidar. Furthermore, the weak education of some public workers in Romania (thus, also in Cenad), ended up "torturing" a number of names belonging to minorities. One such example is that of the family name Jeftic (written Jepmuћ in Serbian orthography with Cyrillic letters), which was written as differently as Ertin, Eftin, Eftici, or Ieftici and which led to numerous pronunciation problems of this name.

Unfortunately, the Latin alphabet as adapted by the neighbours of Romania is scarcely taught in Romania, just like these neighbours do not each in their schools the specific letters of the Romanian alphabet. As a consequence, Romanians are often "re-christened" when crossing the Romanian borders: Șerbănescu becomes Serbanescu; the Romanian citizen of Serbian ethnicity named Cedomir becomes T,edomir when crossing the border (the letter "c" of the Serbian Latin alphabet is the equivalent of the Romanian letter "tw"). There are other examples as well: Jadranka - Iadranca Iadranța, Božidar - Bojidar - Boiidar, etc.

Returning to christening names: the monk Petru Pruteanu from the Republic of Moldova (priest in Portugal from July 2012), being unhappy about the fact that the synaxarium edited annually by the Russian Orthodox Church (on which the Orthodox Church of Moldova depends) does not contain the names of all the Western saints and very few names of the Christian East (of up until 1054), created a list of Eastern orthodox saints who belonged to the Universal Church up until 1054. His list (published on his blog www.teologie.net) gathers over 600 names. He argues: "Therefore, you have the occasion to read not only a list of names of some people from the past, but also the names of some saints whose lives were nothing less than those of the saints of the East (of whom we still do not know a lot, but at least we know their names)." name children with Christian names, but also teach them to live a Christian life and to bless their names! And if, following the discussion with their parents, you manage to convince them to name their children with saint names, then talk to them about the life of that saint and about the ways in which they can resemble the saint's life. $<$ The most beautiful way of honouring saints is by imitating their lives.>"8

It must be highlighted that Petru Pruteanu also edited a version of the synaxarium for clerics and Christians in the Republic of Moldova, noting that "with some exceptions (mentioned in the

\footnotetext{
${ }^{5}$ Ioan Pătruț, Originea și structura antroponimelor românești [The origin and the structure of Romanian names] in Dacoromania VII - VIII (2002 - 2003): 159-163.

${ }^{6}$ Gheorghe C. Moldoveanu, Antroponimia, parte integrantă a tradițiilor culturale românești [Anthroponymy, as an integral part of the Romanian cultural traditions] (Iași: Revista română), 16. http://astra.iasi.roedu.net/pdf/nr62p15-17.pdf (last time accessed: July 6, 2015).

${ }^{7}$ See: www.teologie.net (last time accessed: July 6, 2015).

${ }^{8}$ Ibidem.
} 
footnotes), it can also be used by the clerics and Christians in Romania." ${ }^{9}$ The online publication Lumina, ${ }^{10}$ (edited by the Basilica Media Centre of the Romanian Patriarchy) has an imperative opinion on christening names: "The child must only receive one name when (s)he is christened, because (s)he has one single soul." As the anonymous author writes, "when christened, the child received a sole name because the man has only one birth and only one soul. The christening name represents the soul of the name united with God through the christening, through the rightful faith and through good deeds." Further on, the author highlights: "It is prohibited to name the child with two or even three names at the christening, although this is in fashion today. The name of the saint, given to the child at the christening, makes the newly-christened the disciple of that saint. Through this, the saint becomes the helper and the protector of the Christian child in front of God, during his lifetime, after death, and also at the Last Judgement. A Christian without the name of a saint remains in life without protection and without a constant mediator to God. What is worse than this?"

Unfortunately, some parents do not always realize that they are parents and that they must take certain responsibilities. They have to be conscious that each and every act they do regarding their child may have negative outcomes in the future of their child. This does not have to do with love anymore, but with the truth - a truth which begins at the town hall when declaring the birth of the child. This is the place where one of the parents (usually the father) not only has to acknowledge his heir, but also has to name him/her. And as the Church is no longer a landmark, the place of saints is often taken by football players, actors, film characters, and so on.

The Romanian site www.one.ro created a list of illegal christening names in 10 countries, among which Romania. According to this list, some parents tried to name their children with names such as Tatula Does the Hula From Hawaii (New Zeeland). This name was forbidden but others were allowed such as: Number 16 Bus Shelter, Violence, Metallica, IKEA, Veranda, Brfxxccxxmnpcccclllmmnprxvclmnckssqlbb11116 and Q. „Google” in Sweden. Malaysia adopted a list which did not conform to its religious traditions with names such as: Chow Tow (Dirty Head), An Chwar (Snake), Khiow Khoo (Hump), Sor Chai (Madman) or Woti (Sexual Act). In China (a county where one seldom finds a rare name), one family wanted to name its child with the sign @, which resembles the Chinese expression "love him/her," but the authorities refused the name. Furthermore, Denmark has a list of about 7000 illegal names.

In the case of Romania, we cite an entire paragraph from the afore-mentioned site:

With the support of the authorities, we have among us joyful children with names such as Mirel (first name) Joacă-Bine [plays well], Mariano-Monamur Stelian (first name) Ion, Superman (first name) Sava, Batman Bin Suparman, Bred (first name) Pit, Beckham Figo Zidan (first name) Poenaru, Alexandru-Dick (first name) Păsărică, Tom-Mac-Bil-BobConstantin (first name) Cojocaru, Verginica (first name) Vacăgrasă [fat cow]. Other first names are as following: Strugurel (little grape) appears at 192 people, Portocala (orange the fruit) - 65 people, Ministru (minister) - 22, Lămâia (lemon) - 18, Poliția (police) - 3, Justitia (justice) - 2, Semafor (traffic light) $-1 .^{11}$

The registers of the National Archives of the County of Timiș (to which Cenad belongs) contains dozens of confessional registers. The process of administrative separation from the Serbian Orthodox Church started with the Congress of 1864 in Sremski Karlovci ${ }^{12}$ organized for the election of the patriarch, where the deputy Vincenţiu Babeş presented a document on August 5, 1864, which stood at

\footnotetext{
${ }^{9}$ Monk Petru Priteanu, Iarăşi despre numele de botez. Un scurt Sinaxar al Sfinţilor ortodocşi din Apus [On christening names, once more. A short synaxarion of the Orthodox saints in the East] on the "Liturgică şi misiologie ortodoxă" blog. http://www.teologie.net/2013/09/06/iarasi-despre-numele-de-botez-un-scurt-sinaxaral-sfintilor-ortodocsi-din-apus/ (last time accessed: July 17, 2015).

${ }^{10}$ See the article "Răspunsuri duhovniceşti: Copilul să primească un singur nume la Botez, căci are un singur suflet" [Clerical answers: let the child receive only one name when christened, because (s)he has only one soul] in the Lumina newspaper. See: http://ziarullumina.ro/raspunsuri-duhovnicesti-copilul-sa-primeasca-un-singurnume-la-botez-caci-are-un-singur-suflet-54618.html (last time accessed: July 17, 2015).

${ }^{11}$ See: www.one.ro (last time accessed: July 6, 2015).

${ }^{12}$ Sremski Karlovci - a settlement in the Autonomous Province of Vojvodina, Serbia. This was where the head of the Serbian Orthodox Church in the Habsburg Empire lived starting with 1713.
} 
the basis of the separation. However, the actual separation only began in 1865 , after the Hungarian Royal Chancellery issued an act with reference to the settlements with mixed Orthodox churches, allowing them to "break according to their nationality in two different groups." 13

The Romanian Orthodox Church was established in 1872 by the separation of the Metropolitan Church of Ungrovlahia and the Metropolitan Church of Moldova from the Patriarchate of Constantinople and by naming the Metropolitan of Ungrovahia (also the archbishop of Bucharest) as the Metropolitan of Romania.

The "Descent of the Holy Spirit" Romanian Orthodox Church of Cenad was built between 1888 and 1889 and consecrated on June 9, 1889 on the day of Pentecost. The church starts to have its independent registers, in Romanian, starting with 1876, when the first registered child (on January $7^{\text {th }}$ ) is Vasile, the son of Mitru Nicolasiu and Jela (being married), while the second registered child is Eva (on January $9^{\text {th }}$ ), the daughter of Teodoru Galetariu and his concubine Saveta. Based on its moral norms, the church imposed a special heading, titled "Married or not?" The Following register starts with the last registrations of children christened in 1890 - this is where the importance of the Christian ethics regarding the legitimacy of new-born children is visible. Therefore, a column titled "Legitimate or Illegitimate" was inserted after the registration number, the date of birth and of christening, and after the name and sex of the child - therefore before the names of the parents. Naturally, there were many illegitimate children and the syntagm "child of flowers" (used in Romanian for illegitimate children) followed them imposed by the Church itself. Moreover, a girl "of flowers" was even christened with the name Floare (Flower).

One may notice in the christening records of Cenad names ending in a deaf $u$, which also exsited in old Romanian but eventually disappeared. Also, names starting with the letter $\mathrm{J}$ eventually changed their letter J to I as in: Joanu (Ioan), Jela (Iela) etc.

In order to simplify the statistics, I noticed that some names were spelled differently Ana, Anna; Catița, Catitia, Katitia; Maria, Mărie, Măria, Marie), but the shortened versions of the names as well as the Slavic versions of the names were kept (Jela, Iella, Ielița, Ielitia).

Table 1. Most frequent boy christening names (1876-1903):

\begin{tabular}{|l|c|}
\hline Name & TOTAL \\
\hline Georgiu, George, Georgie & 180 \\
\hline Joan(u), Ioan, Ion & 149 \\
\hline Petru & 48 \\
\hline Nicolae, Nicolau & 48 \\
\hline Pavel(u) & 42 \\
\hline Teodor(u), Todor & 29 \\
\hline Traian(u), Trajan & 26 \\
\hline Antonie, Antoniu & 26 \\
\hline Lazar(u) & 24 \\
\hline Dimitrie, Dimitriu & 23 \\
\hline Vasilie, Vasiliu, Vasilia, Vasalie, Văsălie & 22 \\
\hline Sava & 20 \\
\hline
\end{tabular}

\footnotetext{
${ }^{13}$ Michaela Bedecean, Separația bisericească de Mitropolia din Carloviț în Episcopia Aradului, oglindită în presă (1865-1873) [Church separation in the Metropolitan Church of Karlovci in the Bishopric of Arad, as mirrored in mass media (1865-1873)] (Cluj-Napoca: Anuarul Institutului de Istorie „George Bariţiu“- Seria Historica). http://www.historica-cluj.ro/anuare/AnuarHistorica2009/05.pdf (last time accessed: July 6, 2015).
} 


\begin{tabular}{|c|c|}
\hline Mi(c)hail(u), Michai(u), Mihai(u), Mihaila & 17 \\
\hline Ilie & 16 \\
\hline Aureliu, Aurel & 13 \\
\hline Meila, Meilă & 12 \\
\hline Mitru & 11 \\
\hline $\operatorname{Jovan}(\mathrm{u})$, Iovan & 11 \\
\hline Gavrila (ă), Gavriliu & 10 \\
\hline Tanasiu, Tanasie, Tănasiă & 7 \\
\hline Savu & 7 \\
\hline Marcu & 6 \\
\hline Filip(u) & 6 \\
\hline $\operatorname{Simion}(\mathrm{u})$, Simeon & 4 \\
\hline Paia & 4 \\
\hline $\operatorname{Damian}(\mathrm{u})$ & 4 \\
\hline Atanasie, Atanasiu & 4 \\
\hline Vichentia & 3 \\
\hline Mircu & 3 \\
\hline Jeremia, Irimia, Irimie & 3 \\
\hline Cuzman & 3 \\
\hline Toma & 2 \\
\hline Terentiu, Terentie & 2 \\
\hline Stefan $(\mathrm{u})$ & 2 \\
\hline Romulus(u) & 2 \\
\hline Romul & 2 \\
\hline Alexa & 1 \\
\hline Vincetiu & 1 \\
\hline Victor & 1 \\
\hline Valerie & 1 \\
\hline Urosiu & 1 \\
\hline Traian Ilie Dimitrie & 1 \\
\hline Terentiu & 1 \\
\hline Silviu & 1 \\
\hline Roman (Romulusu) & 1 \\
\hline Rada & 1 \\
\hline Partenie & 1 \\
\hline
\end{tabular}




\begin{tabular}{|c|c|}
\hline Ovid-Corneliu & 1 \\
\hline Octavian & 1 \\
\hline Nestor & 1 \\
\hline Mircea Virgil & 1 \\
\hline Mircea & 1 \\
\hline Mia & 1 \\
\hline Julian & 1 \\
\hline Joan-Josifu & 1 \\
\hline Iosif & 1 \\
\hline Iancu & 1 \\
\hline Horia Tiberiu & 1 \\
\hline Dima & 1 \\
\hline Constandinu & 1 \\
\hline Andreiu & 1 \\
\hline Alia & 1 \\
\hline Alexandru & 1 \\
\hline TOTAL & 818 \\
\hline
\end{tabular}

This table clearly distinguishes the popularity of christening names based on saint names from the Romanian Orthodox Synaxarium: George, Ioan, Petru, Nicolae, Pavel, Teodor. The seventh name in terms of popularity, Traian, is surely given following the name of the Roman Emperor Trajan, the conqueror of Dacia. In this last case, one may suspect this is because of the influence of the School of Ardeal, in terms of national empancipation - between 1876 and 1890, 8 children were christened as Traian, between 1891 and 1900, ten were christened Traian, and between 1901 and 1903, another eight.

During these 27 years, only one triple name was registered (Traian Ilie Dimitrie - 1902, the son of Ștefan and Maria Blagoie) and four double names (Joan-Josifu - 1885, the son of Teodor and Floare Rusu, godparents Josif Müller and Ioana Soceri; Mircea Virgil - 1895, the son of the local priest Gheorghe Telescu and his wife, Floare; Ovid-Corneliu - 1897, the son of the local priest Gheorghe Telescu and his wife, Floare; și Horia Tiberiu - 1899, fiul preotului local Terentiu Oprean și al soției sale, Aurelia). Therefore, of the five multiple names, three belonged to children of local priests. This happened regardless of the Church's argumentation for a single christening name. It is easily observable however, that these names were inspired by the priests' culture and nationalism, Cenad being, during those times, part of Hungary.

A relatively popular name was Meilă (Meila), found 12 times during the studied period. The names of Slavic origin were less popular: Urosiu (Uroș), Mirco (Marcu), Paia, Rada, Jovan (Iovan) being the most popular (11 times). Curiously, in 1897, the name Alia (Alija, the Muslim version for Elijah) appears at the child of Ion and Marta Soceri. Another curiosity is the name Cuzman, with origins in the Iberian Peninsula, but also found in Romanian and Serbian names in the Banat and Crissana Regions. The name of Mia appears only once (1898), probably a shortening for Mihai and Maria for girls.

As a conclusion, 64 christening names were used in the studied period and another three (Virgil, Tiberiu, and Corneliu) were additional names in multiple christening names. A series of names were 
given to children in Romanian-Serbian mixed marriages, the christening being done in the Romanian Orthodox Church of Cenad.

Analyzing the table with the names, it is interesting to notice that out of the 820 boy names, 329 (thus 40,12\%) belong to two names only: George and Ioan, deriving, of course, from their Latin roots - Georgius and Joannes. It should be noted that they are different from the other forms used in other Romanian territories such as Gheroghe and Ion. How can this popularity be explained? It is difficult to believe that the priests of the time explained to their parish the significance of these names, but it may be that they highlighted the importance of the two saints who bore these names: Saints George and John.

The significance of the names: Geroge - the worker of the land in Greek; a first name particularly frequent in Romanian naming, being on the third place after Ion and Nicolae. Ioan - the mercy of God, in Hebrew; the most popular name in Romanian and European naming. Nevertheless, in Cenad, the name George is more frequent than Ioan on the period studied. I believe that in this case, the iconography (including church iconography and icons of the saint in people's houses - in calendars, books, etc.) was determinant. Thus, the image of Saint George slaying the dragon equalled the image which was probably suggested by the priests of the time - that of national liberation. This contrasted the image of Saint John the Baptist who was a model of humility with a tragic end (being decapitated by King Herod and having a suggestive iconography representing this event).

Table 2. Most frequent girl christening names (1876-1903):

\begin{tabular}{|c|c|}
\hline Name & TOTAL \\
\hline Ana (Anna) & 109 \\
\hline Maria (Măria, Mărie, Marie) & 88 \\
\hline Flo(a)re & 72 \\
\hline $\operatorname{Elen}(\mathrm{n}) \mathrm{a}$ & 62 \\
\hline Jela (Iella), Ielița, Ielitia & 39 \\
\hline Roxa (Rocsa) & 37 \\
\hline Marta (Martha) & 35 \\
\hline Saveta (Savetha) & 33 \\
\hline Sofia & 26 \\
\hline Elisaveta & 25 \\
\hline Juliana, Iuliana & 20 \\
\hline Ecat(h)arina & 18 \\
\hline Mi(i)a & 16 \\
\hline Eva & 16 \\
\hline Catița (Catitia, Katitia) & 16 \\
\hline Persida & 14 \\
\hline Lucre(ț)ia & 14 \\
\hline Lena & 12 \\
\hline Vio(a)ra & 8 \\
\hline Ileana (Ilena, Iliana) & 7 \\
\hline
\end{tabular}




\begin{tabular}{|c|c|}
\hline Alca & 7 \\
\hline Sara & 5 \\
\hline Magdolina (Magdolna), Magdalena & 5 \\
\hline Letitia & 5 \\
\hline Veta & 4 \\
\hline Paulina & 4 \\
\hline Anastasia & 4 \\
\hline Stanca & 3 \\
\hline Nasta & 3 \\
\hline Militia (Miliția) & 3 \\
\hline Lenca & 3 \\
\hline Eufemia & 3 \\
\hline Emilia & 3 \\
\hline Dinca & 3 \\
\hline $\mathrm{C}(\mathrm{h})$ ristina & 3 \\
\hline Victoria & 2 \\
\hline Valeria & 2 \\
\hline Solomia (Solomie) & 2 \\
\hline Silvia & 2 \\
\hline Sida & 2 \\
\hline Paraschia & 2 \\
\hline Marina & 2 \\
\hline Ioana & 2 \\
\hline Giula & 2 \\
\hline Elena Floare & 1 \\
\hline Zsivca & 1 \\
\hline Victoria Gizela Persida & 1 \\
\hline Veturia-Emilia & 1 \\
\hline Teodora & 1 \\
\hline Tecla & 1 \\
\hline Sabina & 1 \\
\hline Roxa-Sofia & 1 \\
\hline Rea-Silvia & 1 \\
\hline Rachila & 1 \\
\hline Petra & 1 \\
\hline
\end{tabular}




\begin{tabular}{|l|c|}
\hline Milca & 1 \\
\hline Lillia & 1 \\
\hline Leontina & 1 \\
\hline Lena Ielitia & 1 \\
\hline Jesica Sofia Liubitia & 1 \\
\hline Florica & 1 \\
\hline Fema & 1 \\
\hline Elița (Ielița) & 1 \\
\hline Elisauca & 1 \\
\hline Bosilca & 1 \\
\hline Aurora Livia Adriana & 1 \\
\hline Aurelia & 1 \\
\hline Angelina & 1 \\
\hline Alesandra & 1 \\
\hline TOTAL & $\mathbf{7 6 9}$ \\
\hline
\end{tabular}

In the case of girls, one may find three triple names: Aurora Livia Adriana - 1893, the daughter of the local priest Gheorghe Telescu and his wife Floare; Victoria Gizela Persida - 1901, the daughter of Nicolae and Ana Dămian; Jesica Sofia Liubitia (derived from the Serbian Liubița) 1903, the daughter of Aurel and Lucreția Nicolaș. Furthermore, one may find five double names: Roxa-Sofia - 1894, the daughter of Ioan and Eva Regep; Rea-Silvia - 1887, the daughter of the teacher Georgiu and Miliţia Minisianu; Veturia-Emilia - 1892, the daughter of the priets Gheorghe Telescu and his wife Floare; Lena Ielitia - 1899, the daughter of Valeriu and Floare Terzeu; ElenaFloare - 1900, the daughter of Nicolae and Maria Vințean. The priest Gheorghe Telescu and his wife Floare are once more visible in christening cases with double and triple names.

In the case of girl names, one also encounters Slavicized names: Jela (Iella), Ielița, Ielitia shortened versions of Elena; Catița (Catitia, Katitia) - shortened from Ecaterina; Lenca - shortened for Elena. Furthermore, one can notice even Slavic names in this list: Bosilca - the feminine for Busuioc; Militia, Miliția - corectly Milița; Zsivca (read Jivca); Milca; Dinca (possibly the short version for Radenka or Radinka). There are also less usual Slavic names such as Ferma and Elisauca (possibly a form of the Serbian name Savca). All these changes were most likely the result of the influence of the Serbian Orthodox Church.

Alca is a name which derives from the Muslim name Alka, derived itself from the name Alia (Alija, in Bosnia and Herzegovina). It seems that collective memory had its influence on both names (Alia and Alca): after 164 years of Ottoman domination in Banat, one may still find in Cenad the family name of Regep (Rejep), which is surely of Turkish origin, although one cannot speak of Turkish families in Cenad.

In the table above, one may clearly distinguish the popularity of the name Ana (109 entries) and Maria (88 entries). However, should one gather all the names of Elena with its derivates Ileana (Ilena, Iliana) and its Slavic forms (Jela - Iella, Ielița, Ielitia, Lenca), this name should appear as the most popular one (120).

The significance of the names: Ana - meaning goodwill, mercy in Hebrew; one of the most wellknown and popular name in Christian naming because of its history and its direct origin from the Old and the New Testament; Maria - meaning sea of sadness in Egyptian, beloved; feminine fist name 
with the largest spreading within all the continents; Elena - helene $=$ torch, fire; or selene $=$ moon (Greek), one of the most popular female names in Romania.

Christians consider Saint Anna to be the mother of Virgin Mary and the grandmother of Christ this is one explanation for the popularity of the name in Cenad. As for the name Elena (Saint Helen being the mother of Emperor Constantine the Great, the Romanian Orthodox Church celebrating the two saints together), with its derivates Lena, Ilena, Ileana: its popularity may be explained in terms of fashion because the iconography of Saint Helen is not as frequent and expressive as that of the Virgin Mary, for instance.

Between 1976 and 1903, 16 pairs of twins were recorded in Cenad, five of which were boys, seven girls, and the other four mixed. Two of these pairs (George and Mitru from the parents Terentiu Minisian și Veta Covaciu; and Ioan and Saveta from the parents George și Saveta Rezsep) were born on the same day: January $17,1878$.

As a final observation, making a numerical analysis, the number of new-borns was in a permanent decline during the studied period. Most children were born in the year 1878 ( 75 children), and the less were born in 1891 (39). The total number of boys (1876-1903) was 820, and that of girls was $769-$ there were 51 more boys born than girls, as if nature was preparing itself for the First World War (1914-1918).

During the last four years which were studied (2010-2013), 170 children originating fom Cenad were registered, 78 of whom were boys and 92 girls. However, this is not a study of birth rates, but of name trends in Cenad. Therefore, although until recently, mixed marriages were rare and parents together with their families and godparents preferred to choose classical names, especially inspired from religion (Ioan, Maria, Andrei, Pavel, Gheorghe, Ana, etc.) or flower names (Florica, Viorica). In the present however, they opt for new or foreign names. Some of the reasons for this may be television, cinematography, and, lately, the time spent by parents or godparents working in foreign countries. Furthermore, while until recently double, triple, or multiple names were rare, now single names became just as rare, most people preferring at least two christening names for their offspring.

The statistics generated based on the registers of the Cenad Town Hall, reveal that the most popular names for boys between 2010 and 2013 are: David, Daniel, Sebastian and Patrick (AngloSaxon names, although there are no Irish, English, or Scottish inhabitants in Cenad).

Table 3. Most popular boy names (2011-2013):

\begin{tabular}{|l|l|l|l|l|l|l|}
\hline $\begin{array}{l}\text { David } \\
\text { Adrian }\end{array}$ & $\begin{array}{l}\text { Daniel } \\
\text { Denis }\end{array}$ & $\begin{array}{l}\text { Patrick } \\
\text { Georgian }\end{array}$ & $\begin{array}{l}\text { Sebastian } \\
\text { Bogdan }\end{array}$ & $\begin{array}{l}\text { Marius } \\
\text { Bogdan }\end{array}$ & $\begin{array}{l}\text { Andrei } \\
\text { Alexandru }\end{array}$ & $\begin{array}{l}\text { Mario } \\
\text { Daniel }\end{array}$ \\
\hline $\begin{array}{l}\text { David } \\
\text { Alexandru }\end{array}$ & Daniel & Patrick & $\begin{array}{l}\text { Sebastian } \\
\text { Lucian }\end{array}$ & $\begin{array}{l}\text { Marius } \\
\text { Bogdan }\end{array}$ & $\begin{array}{l}\text { Andrei } \\
\text { Ionuț }\end{array}$ & $\begin{array}{l}\text { Mario } \\
\text { Florin }\end{array}$ \\
\hline $\begin{array}{l}\text { David } \\
\text { Catalin }\end{array}$ & Daniel & $\begin{array}{l}\text { Patrick } \\
\text { Sebastian }\end{array}$ & $\begin{array}{l}\text { Sebastian } \\
\text { Marian }\end{array}$ & $\begin{array}{l}\text { Marius } \\
\text { Nikolas }\end{array}$ & $\begin{array}{l}\text { Andrei } \\
\text { Paul }\end{array}$ & Mario \\
\hline $\begin{array}{l}\text { David } \\
\text { Nicolae }\end{array}$ & Daniel & Patrick & Sebastian & & & \\
\hline $\begin{array}{l}\text { David } \\
\text { Valentin }\end{array}$ & & Valentin & & & \\
\hline David & & & & & & \\
\hline
\end{tabular}

Other names: Adelin Marian, Antonio Vasile, Bojidar, Călin Gabriel, Cătălin Marina, Ciprian Marian, Claudiu Ionuț, Cosmin Constantin, Darius Mitruț, Emanuel Alexandru, Ervin Atila, Fabian Gabriel, Flavius Cristian, Ioan Paul, Iosif Adrian, Iustin Gabriel, Leonard, Luca Adrian, Lucas Țvetomir, Lucian Gabriel, Mădălin Alin, Manuel, Marco, Miroslav Stevan, Narcis Anton, Nicholas, Nicolas Dragoș, Norbert Denisz, Ovidiu, Paul Dragoș, Peter, Petru Cristian, Rareș Alexandru, Rareș Mihai, Raul Ilie, Raul Ionuț, Răzvan Andrei, Robert Cristian, Robert, Sergio Cosmin, Stefan Daniel, Vlad Emanuel, Zlatan Ionatan.

This study only analyzed the first name of the multiple christening names, the order of preferences thus becoming clear. However, should one also consider the second or third christening names, the situation would suffer alterations. 
In the case of girls, the diversity of names is somewhat larger, the most popular being Natalia (Nataşa), Giorgiana (Georgiana), and Maya (Maia). It should be noted that although the name Maria appears only once as a first preference, it is found 13 times as a second option.

Tabelul 4. Most popular girl names (2011-2013):

\begin{tabular}{|l|l|l|l|l|l|}
\hline $\begin{array}{l}\text { Natalia } \\
\text { Albertyna }\end{array}$ & $\begin{array}{l}\text { Georgiana } \\
\text { Simona Maria }\end{array}$ & Maia Florina & Alesia Evelin & Amalia Raluca & Daria Giorgiana \\
\hline $\begin{array}{l}\text { Natalia } \\
\text { Albertyna }\end{array}$ & Giorgiana Ioana & Maya & $\begin{array}{l}\text { Alesia } \\
\text { Stefania }\end{array}$ & Amalia Stefania & Daria Maria \\
\hline Natalia Ariana & Giorgiana Ioana & $\begin{array}{l}\text { Maya } \\
\text { Alessia }\end{array}$ & $\begin{array}{l}\text { Alessia } \\
\text { Gabriela }\end{array}$ & Amalia Stefania & Daria-Ionela \\
\hline Natalia Ștefania & $\begin{array}{l}\text { Giorgiana } \\
\text { Mădalina }\end{array}$ & Maya Ioana & & & \\
\hline Nataşa Mileva & & & & & \\
\hline
\end{tabular}

Other girl names: Adelina Daniela, Adriana Daria, Adriana Radmila, Aida Denisa, Alexandra Cristina, Alexandra Gabriela, Alexia Adelina, Alexia Rebeca, Ana Maria Lucreția, Andra Maria, Andrada Ionela, Andreea Valentian, Andreea Victoria, Antonia, Ariana Alexandra, Beatris Andreea, Bianca Maria, Camelia Julia, Clara Ildiko, Corina Simona, Cristina Mihaela, Cristine Ioana, Delia Florina, Diana Casandra, Diana Georgiana, Elena Andrada, Elisa Mariana, Erika Gabriela Ildiko, Evelina Maria, Eveline Vivian, Ianna Maria, Iohana, Irina Victoria, Isabela Maria, Iulia Maia, Izabela, Julia, Karina Maria, Karina Maria, Kataleya Maria, Laura Eliza, Lavinia Maria, Lidia Monica, Lorena Maria, Madalina Gianina, Maria Mirabela, Miriam Ioana, Miruna Roberta, Narcisa Adriana, Nicol Stefania, Nicoleta Giorgiana, Olivia Paula, Patricia Alexandra, Patricia Maria, Romina, Roxana Ioana, Roxana Maria, Sara, Simona Flavia, Slagiana, Slagiana Milena, Stefania Amalia, Svetlana, Svetlana Maria, Tamira Andrada, Tania Alina, Vesna Ana, Viorica Florina

In the case of mixed marriages, one may notice that some names were given according to the nationality or tradition of one of the parents (usually, following the nationality of the father).

Based on all this information, one may conclude in the end that everything changes, including names. Having no constraints (religious, moral or administrative), the christening name has no significance anymore (both in Cenad, and generally speaking as we may continue broadening this study on a more general setting). The christening name thus remains a trifle of the parents, dictated by fashion, feelings, passions, etc.

\section{References}

Serviciul Județean Timiș al Arhivelor Naționale [The National Archives of the County Service of Timiș], Fond 4, Colecția Registre de stare civilă [The collection of marriage registers], Parohia Ortodoxă Română Cenad [The Romanian Orthodox Parish of Cenad], file no. 1 - Christened between 1876-1890 and file no. 2 - Christened between 1891-1904.

Consiliul Local Cenad, Primăria Cenad [The Local Council of Cenad, Town Hall of Cenad], Ghidul cenăzeanului [The Guide of the Cenad citizen]. Years 2010, 2011, 2012, 2013.

Popovici, Bogdan-Florin. Considerații pe marginea prelucrării colecţiei de registre de stare civilă [Considerations on managing the collections of marriage registers] on https://bogdanpopovici2008.files.wordpress.com/2009/01/stare-civila-ver-2.pdf. (last time accessed: July 8, 2015).

Dicționarul Explicativ al Limbii Române [The Romanian Explicative Dictionary] on http://dexonline.ro/ (last time accessed: July 8, 2015).

Pruteanu, Petru, Iarăşsi despre numele de botez. Un scurt Sinaxar al Sfinţilor ortodocşi din Apus [On christening names. A short synaxarion of Orthodox saints in the East] on http://www.teologie.net/data/pdf/sfinti-ortodocsi-apus.pdf (last time accessed: July 8, 2015). 
Răspunsuri duhovniceşti: Copilul să primească un singur nume la Botez, căci are un singur suflet [Clerical answers: Let the child receive only one name when christened, because (s)he only has one soul]. In Lumina, 14 August 2008. On http://ziarullumina.ro/agenda-crestinului/raspunsuriduhovnicesti-copilul-sa-primeasca-un-singur-nume-la-botez-caci-are-un (last time accessed: July 8, 2015).

Moldoveanu, Gheorghe C., Antroponimia, parte integrantă a tradițiilor culturale românești [Antroponymy, an integral part of the Romanian cultural traditions]. Iași: Revista română. On http://astra.iasi.roedu.net/pdf/nr62p15-17.pdf (last time accessed: July 8, 2015). 